\title{
Intelligence Search with WISC Test Equipment for Students with Attention Deficit and Hyperactivity Disorder (ADHD)
}

\author{
Hayatun Thaibah \\ Special Education Study Program \\ Universitas Lambung Mangkurat \\ Banjarmasin, Indonesia \\ hayatun.thaibah.plb@ulm.ac.id
}

\begin{abstract}
Attention Deficit and Hyperactivity Disorder (ADHD) is a developmental disorder in the form of an unusual increase in children's activities and tends to be excessive. This is characterized by various complaints of feeling restless, unable to be quiet, unable to sit quietly and always leaving a permanent situation such as sitting or standing. The purpose of this study was to determine the intelligence of students with ADHD barriers using test instruments Wechsler Intelligence Children Scale (WISC). This research is a descriptive-quantitative study. The subject of this study was 19 students with impaired concentration and hyperactivity at SDN X Martapura, Indonesia. The research showed that based on WISC intelligence test result, among students who have ADHD barriers there are 1 student $(5.3 \%)$ with a category above the average, 8 students $(42.1 \%)$ with an average category, 6 students $(31.6 \%)$ with a category below the average, 2 students $(10.5 \%)$ with a border category and 2 students $(10.5 \%)$ with a category of mental retardation. It can be concluded that the intelligence of students with ADHD barriers lies in the category above the average, average, below average, border and mental retardation.
\end{abstract}

Keywords-Intelligence, WISC Test, Attention Deficit and Hyperactivity Disorder (ADHD)

\section{INTRODUCTION}

Ref [1] define Children with Special Needs are children who have differences in several dimensions of humanity, namely physically, intelligently, and socially emotionally that do not function, thus inhibiting their humanitarian functions, such as deafness, blindness, disorder talk, physically disabled, mental retardation and emotional disorders. Ref [2] explain children with special needs from the point of view of education are different from students in general. Obstacles that are carried by various kinds both mentally, learning disorders due to difficulty focusing in one thing, social and emotional disorders, limitations in communication, physical, hearing, vision, autism and intelligent special and special talents, these differences then the educational needs must be specifically, taking into account things such as the character needs of each student with special needs.

Over time and see the development of children with disabilities that are increasingly rapid - developments in developing the potential that can be developed and even that potential can exceed normal children. An understanding of the rights of every child in education does not have the same discrimination even though including for persons with disabilities, the eyes of the world are increasingly open about the education of persons with disabilities so that potential disability advocates can develop. Inclusion education emerged, where children with disabilities have the right to get education services in regular schools with friends of their age. This education model seeks to provide equal opportunities for all children including disability advocates to get the same learning opportunities, equal access from learning resources and infrastructure in optimizing the potential of persons with disabilities.

The implementation of Inclusive Education involves various parties to be able to benefit maximally - inclusive education in schools that must be involved starting from the principal, class teacher, school friends, and all school members. The community starts from the highest order, namely policy makers, and the environment around children and industry as a place for children to explore the potential after finishing learning. The family really needs material and non-material support to support the continuity of learning.

Children with special needs are children who experience physical, social, emotional, behavioral, intellectual obstacles, so they are influential in learning and need help specifically in the field of education. The concept of inclusive education has emerged which provides facilities for children with special needs to be able to obtain proper education in public school institutions.

Hyperactive behavior is a movement that is carried out in excess of the movement of a child of his age. Hyperactive behavior usually starts at the age of 3 years, but generally, it is only detected after the child sits in elementary school, when formal learning situations require a controlled pattern of behavior, including concentration and good concentration. The main characteristic of this disorder is the tendency to move from one activity to another without being able to complete the task given, unable to properly concentrate when doing a task that demands cognitive involvement, and the impact of irregular, excessive, and disruptive activities. The symptoms of hyperactivity, among others, are as follows: very easy to be 
confused, often forget, often difficulty in carrying out tasks at school or while playing due to lack of attention to activities and have a lack of attention when talking and playing with others.

Hyperactive children and adults have a very high level of activity, either in the form of physical or verbal activity constant and constant motion. Hyperactive individuals often feel anxious, talk a lot and often interrupt others. Their behavior tends to be hard and annoying or disruptive. They also have difficulty managing their activities that have an impact on the emergence of major problems in social, school and work situations. Hyperactive individuals basically have the following behavior to talk a lot, can't be calm/silent, have a need always to move, always make noise, always hold what is seen, it is difficult to sit still, more agitated and impulsive compared to those who are of the same age and like to scream.

The search for the characteristics of the intelligence test results for ADHD (Attention Deficit Hyperactivity Disorder), children needs to be done, given the impact of ADHD on the future of children's education later and given the limited handling that can be done by parents, schools and the community. In addition, children with ADHD are aware that the number is increasing, although there are no definitive statistics in Indonesia. Furthermore, children with ADHD are also the next generation of the nation. If children with ADHD do not get the right handling assistance, their future will be bleak with the possibility of various unexpected risks. Compared with peers, children with ADHD are more at risk of serious accidents, school failures and school dropouts, limitations in social adjustment, problems of behavior violations (child delinquency) to legal violations (criminal acts), and earlier abuse of drugs [3] [4]. It is hoped that by tracing the characteristics of intelligence tests results can be known how to help children with ADHD overcome obstacles in actualizing their intelligence potential, both parents and teachers can help prepare the future of their education through tutoring that is appropriate to the characteristics of children with ADHD.

The WISC test is an intelligence test commonly used to measure the intelligence level of children aged 5 to 15 years. The WISC test has the ability to describe various aspects of a child's intelligence, such as insight and interest in knowledge, power of concentration and short-term memory, various abilities, such as language, mathematics, logical and abstract thinking, visual motoric coordination, visual perception organization, visual-spatial relationship and field dependence, adaptation to the environment and understanding of social norms (related to anticipation of social problems and social skills), and creativity. Some studies have used the WISC test to uncover symptoms of clinical disorders in children, such as main brain dysfunction /brain damage, emotional disturbances, anxiety, delinquency, learning disabilities, and others [5].

Considering the WISC test capabilities describing various aspects of children's intelligence and the WISC test has been used in various studies, the authors did not hesitate to study the characteristics of the results of children's intelligence tests with ADHD from the WISC test. In addition, the author also considers adaptation and standardization of WISC tests conducted in Indonesia. Thus, the advantages of using the
WISC test are far more so that they can overcome the weaknesses of the administration of the WISC test, which must be done individually and requires more time and effort. The researchers were even more confident in using the WISC test after making observations in the field. Field observations found that children with ADHD had several behavioral characteristics, including difficulty in concentration in learning, so it was not easy to survive in the long and difficult attention span of storing information that had been learned overnight to be maintained until school during the test.

Based on information obtained, children with ADHD barriers are often left behind and ultimately do not finish doing their assignments at school. In addition, it is quite often found that their writing is incomplete, there are certain letters or certain numbers that are missing, or there are words/sentences that have passed. Even students with ADHD barriers can also experience wrong viewing or reading punctuation $(+,-,:$, and $\mathrm{x}$ ), words and sentences. Most of the students with ADHD barriers have poor handwriting and are complained about by children with ADHD problems because it is difficult to read. Children with ADHD barriers are like dyslexia. This condition makes the researchers want to know the child's spasms with ADHD resistance through the WISC test. Parents also complain of reports from school teachers that children with ADHD are often left behind or not finished

Hyperactivity or hyperactivity is an excessive movement, surpassing the movements carried out in general by his age. Usually, since a baby, they move a lot and are hard to calm. Children are not able to control and coordinate their motor activities so that important and unimportant movements cannot be distinguished. His movements were carried out continuously without getting tired so that it was difficult to focus attention [6]. The hyperactive behavior in ADHD children is characterized by the following symptoms often uneasy with hands and feet that are constantly moving, often leaving a seat in the classroom or in other situations where it is expected that the child stays seated, often running around or riding in excessive situations where this is inappropriate (in adolescence or adulthood limited to subjective anxiety), often having difficulty playing or engaging in quiet leisure activities, often moving or acting as if controlled by a motorbike, often over talking.

Child problems with hyperactive behavior are problems in school. Children are not able to follow the lessons delivered by the teacher well. An easily disturbed concentration makes the child unable to absorb the subject matter as a whole. A short attention span makes you want to finish when doing school assignments quickly. The tendency to speak highly will disturb children and friends invited to talk, therefore the teacher will think that the child does not pay attention to the lesson [7].

Problems at home, hyperactive children are usually more easily anxious and discouraged. In addition, he is also easy to experience psychosomatic disorders (health problems caused by psychological factors) such as headaches and stomach aches. This is related to the low tolerance of frustration so that if you experience disappointment, it is easy to emotion. In addition, hyperactive children also tend to be stubborn and easily angry if their wishes are not fulfilled [7]. 
The problem of talking, hyperactive children usually like to talk. Children talk a lot, but actually, they are not effective in communicating. Disruption of attention concentration makes it difficult to make reciprocal communication. Hyperactive children tend to be busy with themselves and unable to respond to the other person appropriately [7]. Physical Problems, in general, hyperactive children have a level of physical health that is not as good as other children. Some disorders such as asthma, allergies, and throat infections are common. During sleep, active children are usually not as calm as other children. Many hyperactive children have difficulty sleeping and often wake up at night.

In addition, the high level of physical activity of children who are at high risk for accidents such as falls, knots, etc. [7]. ADHD children who have hyperactive behavior have causative factors such as brain imbalance; the researchers get an interesting picture, namely the left brain and right brain ADHD sufferers work at different speeds. The right brain is much more active than the left brain. Therefore, a treatment that matches the cause is balancing the left brain and right brain. The term ADHD which has recently been heavily discussed is a medical condition that includes brain dysfunction, when a person has difficulty controlling impulses, inhibits behavior, and does not support easily distracted attention span or attention span [6].

In general, $\mathrm{ADHD}$ is a condition when a person shows symptoms of lack of concentration, hyperactivity, and impulsivity which causes an imbalance of most living activities [8]. Ref [9] defines ADHD as a disorder when the response is hindered and experiences dysfunction that leads to a lack of self-regulation, lack of ability to regulate behavior for present and future goals, and difficult to adapt socially and behavior with environmental demands. Ref [7] says the notion of the term hyperactive child is a child who shows a pattern of behavior that persists in a child. This behavior is characterized by an attitude of not being quiet, being unable to concentrate, and acting as he wishes or impulsively. ADHD is a very complex condition with different symptoms. Experts have different opinions on this matter. However, in general, ADHD is divided into three types, namely, the type that cannot focus, the type of hyperactive and impulsive child, and the combined type.

In general, problems that are often experienced by ADHD children are difficult to control behavior, difficulty concentrating, and it is difficult to sit still for some time. DSMIV (Diagnostic and Statistical Guide to Mental Disorders, the latest classification of mental disorders by the American Psychiatric Association), an important feature of hyperactivity disorder is less attention about the difficulty of focusing attention and/or visible hyperactive and impulsive behavior more often and more severely than is commonly seen in other individuals.

Based on some of the above meanings it can be concluded that ADHD children experience disorders caused by brain dysfunction, where individuals will have difficulty controlling behavior, disrupting concentration and acting as they wish or impulsively.
The main characteristic of this disorder is the tendency to move from one activity to another without being able to complete the task given, unable to properly concentrate when working on a task that demands cognitive involvement, and appears, and appears to be irregular, excessive, and screw up [6]. Lack of attention is one of the symptoms of ADHD. Usually, children always fail to pay enough attention to detail or children always make mistakes because they are careless when doing school work, work or other activities. ADHD children also often find it difficult to maintain concentration when playing or working, often not listening when invited to talk, and or forgetful in daily activities. Ref [10] argues that the symptoms that appear for six months in hyperactive children for each type include the following, namely the type of hyperactivity intensity, symptoms of deviant behavior and the level of development that are not constant; impulsive hyperactive type symptoms arise from conscientious hearted behavior, do not like to be quiet in activities, and often interfere with others; and the type of mixed hyperactivity between type 1 and 2 appears symptomatic of a level of irregular development that lasts for 6 months accompanied by symptoms of deviant behavior, lack of concentration, indifference, and likes to disturb others.

Ref [6] argues that ADHD is better known as hyperactive children because they always move from one place to another. Children with $\mathrm{ADHD}$ cannot sit quietly in a place for $\pm 5-10$ minutes to do the activities given to them. The concentration range is very short, easily confused and his mind is always chaotic, often ignoring orders or directions, often unsuccessful in completing assignments at school. Often have difficulty spelling or imitating the spelling of letters. These children have difficulty focusing and concentrating long enough to complete their assignments. Characteristics of children with ADHD include the following: hyperactivity, perceptual motor disorders, emotional lability, overall coordination deficit and attention disorders (short attention span, distractibility, hardheartedness, failure to solve things, intensity, poor concentration); Impulsivity (acting before thinking, changing behavior suddenly, not having an organization, jumping up and down at school); memory and mind disorders, specific learning disabilities; speech and hearing disorders; as well as vague neurological signs and EFG irregularities. The other characteristics of ADHD are as follows: they cannot pay attention in detail, make careless mistakes in school work, work or other activities; easily distracted, has difficulty paying attention to tasks, especially on long and tedious tasks; seemed not to pay attention when invited to talk directly, maybe daydreaming, his mind was somewhere even when there was no interference; have difficulties with the organization. Avoid or dislike activities that require continuous mental effort; often eliminate items and often forget.

Factors that cause ADHD from a lot of research and study, but there is no single definite cause that seems to apply to all existing disorders. Viruses, hazardous chemicals that are often found in the environment, both home and outside in the form of factory waste, genetic factors from one parent or the genetics of both parents, problems during maternal pregnancy and at birth, or whatever which can cause damage to brain development plays an important role as a factor causing ADHD [8]. 
There are several factors that cause children to become $\mathrm{ADHD}$, including the following genetic factors. It seems that certain receptors in the brain that usually respond to neurotransmitters called dopamine do not work properly. Most likely, dopamine is not produced at normal levels in the brain. This dopamine deficiency interferes with cognitive processes such as focus and attention. This finding increases that ADHD evidence is a hereditary condition. Children with ADHD tend to have one close relative who is also ADHD. One-third of ADHD sufferers as children have children who also have ADHD. ADHD is more common in men than women with a ratio of $3: 1$. Special gene studies, some findings show that genetic molecules of certain genes can cause ADHD. Thus, findings from aspects of the family, twins, and certain genes state that ADHD has something to do with offspring. Neurological factors, which are higher hyperactivity indications, are found in babies born with prenatal problems such as the length of labor, fetal distress, labor with carrra extract of forceps, toxemia gravidarum, or eclampsia compared to normal pregnancy and labor. In addition, factors such as babies born with low weight, mothers who are too young, and mothers who smoke and drink alcohol also increase the incidence of hyperactivity.

Several studies have shown the occurrence of impaired blood perfusion in certain areas of hyperactive children, namely the striatum blood, the prefrontal orbital region, and the brain's orbital regions, especially the right side. According to [6] there are some conjectures from the discovery of neurobiologists including that there are similarities between the characteristics that appear in ADHD and those that appear in the damage to the function of the prefrontal lobe. Likewise, the reduction in ability in ADHD children on neuropsychological tests is associated with the function of the prefrontal lobe. Findings through MRI (high-tech brain examination) show there is abnormal Pafa front part of the brain. This section includes the prefrontal cortex which is often associated with the lower part of the cerebral cortex collectively known as the ganglia ward. This part of the brain is related to attention, executive function, delay in response, and organizational response. Damages to this area give rise to features similar to those of ADHD. Other information that ADHD children have a smaller prefrontal cortex than children who are not ADHD.

Some of the toxins that cause allergies and additives in possible foods can be the cause of hyperactive disorders (ADHD) in recent years. Additives in some types of food consumed daily, such as artificial dyes, food seasonings, and food preservatives have an impact on the occurrence of hyperactive disorders in children. Another cause of hyperactivity disorder that occurs in a child is a pregnant woman has a smoking habit. A pregnant woman who is addicted to cigarettes can be made possible to cause children born to have hyperactive disorders. Chances are 3 times compared to pregnant women who don't like smoking.

Brain and metabolic disorders, namely birth trauma or hypoxia, which affect the frontal lobe in the brain; reduction in cerebral volume; astrocyte dysfunction in the formation and provision of lactate, as well as impaired oligodendrocyte function. Some theories that are often put forward are the relationship between neurotransmitters dopamine and epinephrine.

Identification procedures to make proper identification, need to pay attention to things as follows the parent's perspective includes several things, namely careful interviews, such as a review of the characteristics, development history, characteristics of parental depression, other influences of traits that appear in children against parents; check sheet must be a child; question of home situation; development history form; and marriage adjustment surveys using findings from LockeWallace.

The child's perspective includes several things, namely interviews, IQ examinations, presentation tests, studies on the state of the school, and observations of parent and child interactions. The school perspective includes several things, namely discussions with parents, classroom observations, teacher assessment forms or behavioral rating scales with Kendall-Wilcox instruments and ADHD specific needs. An ADHD child has difficulty doing the action process or adjusting to his environment [6]. This situation requires arrangements that allow children to control themselves in all their actions. Based on this, there are several things that ADHD children need, including self-control needs, self-control needs more related to reducing or eliminating hyperactivity.

Therefore what is needed by ADHD children is routine, structure, and consistent with the rules clearly and their consequences if the child violates these regulations. Consistency in applying discipline, giving rewards for positive behavior and applying consequences or penalties must be consistent so that children are not confused. Focus on positive things, namely giving rewards for positive efforts that the child has done even though the results have not been satisfactory. Find activities that children love and develop their abilities optimally so that children can be proud of. Simple and brief explanations so that children can understand what is being said other, explanations must be given with simple, short words, and in a calm situation. It is strongly recommended to use a flat, monotonous and firm tone of voice when talking to children. Avoid arguments and debates, namely by giving orders or prohibitions briefly and firmly. Ignore protest comments from children, by giving too much explanation because it will lead to argumentation. Ignore things that are not important by making a list of behaviors that are a priority in a child's life such as avoiding danger, not acting aggressively, doing school work as well as possible. Things that are not a priority should not be made too much of a problem so that the child is not frustrated.

Failure to learn ADHD children is more due to children having difficulty controlling themselves. Emotional impulses that arise such as getting out of the seat, the act of impulsivity that can be controlled is very detrimental to one's own children and others. To learn children need a calm, conducive, and controlled environment. Classroom management by paying attention to the diversity of students, if it can be applied helps create an atmosphere that all children can learn.

This study aims to determine the intelligence of students of Attention Deficit and Hyperactivity Disorder (ADHD) using the Wechsler Intelligence Children Scale (WISC) test. 


\section{METHOD}

This study uses a type of descriptive research with a quantitative approach that aims to reveal something as it is. Ref [10] reveals that descriptive research is not intended to test certain hypotheses, but only describes what it is about a variable.

The sampling technique in this study was "purposive sampling" or the technique of determining the sample with particular consideration. The sample of this study was students who experienced obstacles in attention and behavior recorded in the school of SDN X Martapura. Students consist of grade 1 to grade 6 elementary schools.

The data analysis of the researchers used quantitative descriptive analysis. Analyze data by describing or describing data that has been collected as it is without the intention of making conclusions that apply to the public or generalizations [11]. Research subject: The subject of this study was 19 students with impaired concentration and hyperactivity at SDN $\mathrm{X}$ Martapura, Indonesia. Research procedure: The procedure in this study is to record students who have been identified by the accompanying teacher Students with Special Needs. After obtaining data from the school, there were as many as 60 students identified as students with special needs, namely grahita, slow learning and attention disorders, and hyperactivity. There were 19 students with ADHD barriers. Then the students have carried out intelligence tests first to get student IQ scores. Intelligence test results were examined then analysis was carried out in the form of looking for percentages of each category obtained by students with ADHD barriers using test instruments Wechsler Intelligence Children Scale (WISC). The WISC test is an intelligence test commonly used to measure the intelligence level of children aged 5 to 15 years.

\section{RESULTS AND DisCUSSION}

TABLE I. RECAPITULATION OF ADHD STUDENT INTELLIGENCE TEST RESULTS

\begin{tabular}{|c|c|c|c|}
\hline Name & Obstacles & IQ & Category \\
\hline MMR & ADHD & 114 & High Average \\
\hline FD & ADHD & 96 & Average \\
\hline MARM & ADHD & 93 & Average \\
\hline AYW & ADD & 101 & Average \\
\hline HLP & ADD & 72 & Borderline \\
\hline ASE & ADHD & 89 & Below average \\
\hline MD & ADHD & 93 & Average \\
\hline SHA & ADHD & 75 & Borderline \\
\hline ASK & ADD & 64 & $\begin{array}{l}\text { Retardation } \\
\text { Mental }\end{array}$ \\
\hline $\mathrm{N}$ & ADD & 86 & Below average \\
\hline SA & $\begin{array}{l}\text { ADD and } \\
\text { communication }\end{array}$ & 90 & Average \\
\hline ADM & ADD & 106 & Average \\
\hline NK & ADD & 82 & Below average \\
\hline NF & ADD & 93 & Average \\
\hline $\mathrm{MH}$ & ADD & 86 & Below average \\
\hline SR & ADD & 85 & Below average \\
\hline AVT & $\mathrm{ADD}$ & 67 & $\begin{array}{l}\text { Retardation } \\
\text { Mental }\end{array}$ \\
\hline MDS & ADD & 106 & Average \\
\hline GMH & $\mathrm{ADHD}$ & 81 & Below average \\
\hline
\end{tabular}

The results of the study obtained from the results of intelligence tests using WISC that students who have ADHD barriers can be seen there are 1 student with a category above the average, 8 students with an average category, 6 students with a category below the average, 2 students with a category border and 2 students with mental retardation categories.

\section{Intelligence Test Results for Students with ADHD disorders}

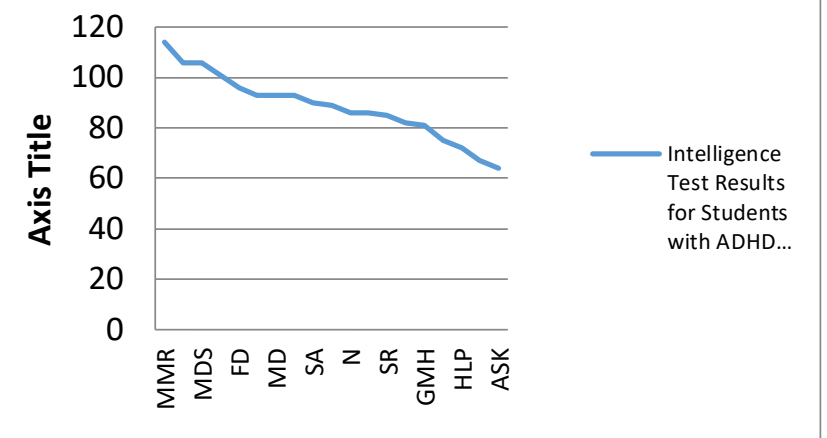

Fig. 1. Student Intelligence Test Results with ADHD

Based on the results of the percentage obtained on the intelligence test of students with ADHD can be seen in Table below:

TABLE II. Percentage OF InTELLIGENCE TEST Results For STUDENTS WITH ADHD

\begin{tabular}{|l|l|l|}
\hline \multicolumn{1}{|c|}{ Category } & \multicolumn{1}{c|}{ Total } & \multicolumn{1}{c|}{ Percentage } \\
\hline High Average & 1 & $5.3 \%$ \\
\hline Average & 8 & $42.1 \%$ \\
\hline Below Average & 6 & $31.6 \%$ \\
\hline Borderline & 2 & $10.5 \%$ \\
\hline Mental Retardation & 2 & $10.5 \%$ \\
\hline Total & 19 & \\
\hline
\end{tabular}

The table shows that students with ADHD are known to be $5.3 \%$ with a category above the average; $42.1 \%$ with an average category; $31.6 \%$ with a category below the average; $10.5 \%$ with border categories and $10.5 \%$ with mental retardation categories.

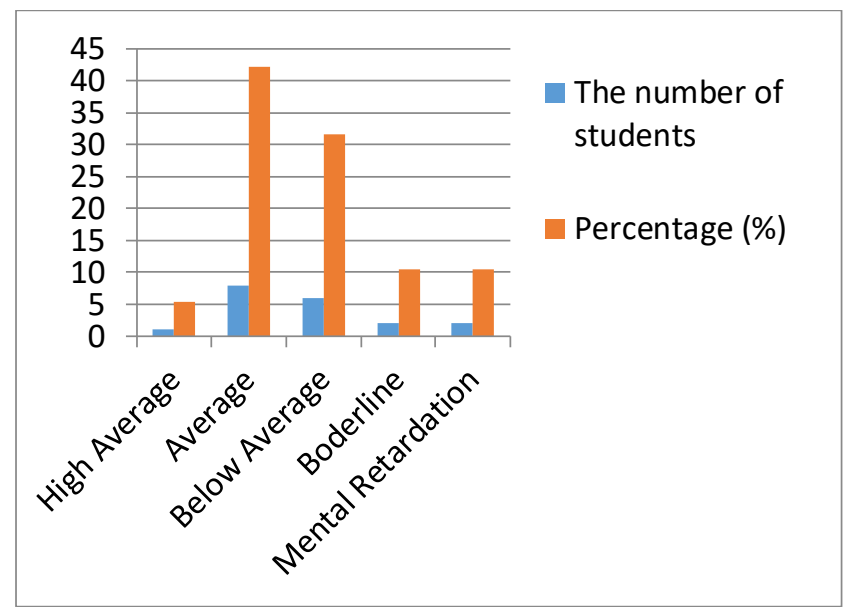

Fig. 2. Percentage of Intelligence Test Results for Students with ADHD 
The research that has been conducted aims to determine the intelligence of students with Attention Deficit and Hyperactivity Disorder (ADHD) barriers using the Wechsler Intelligence Children Scale (WISC) test equipment. The results showed that students with ADHD barriers had intelligence levels belonging to the category above average, average, below average, border and mental retardation.

General intelligence tests can also be used to diagnose the causes of failure of children in school. Often teachers and parents of children in elementary schools find irregularities in children and students like their lessons become less fluent and achievements at school are low even though previously the child has a brilliant achievement. Intelligence tests can help find the cause of low achievement, especially if abnormalities occur in the mental field. In addition to using intelligence tests, it can also be helped by using aptitude tests and personality tests to find out other factors other than children's intelligence factors, such as lack of motivation to learn, poor environmental conditions in the family, school or society, or abnormalities. Physical abnormalities of children consist of visual acuity abnormalities, hearing disorders, and so on.

Family and environment (school, community) are very important in developing intelligence; this is because the development of intelligence is strongly influenced by stimuli that come from the environment as well as factors of experience, education, and training. Health factors or parent's descendants can influence children's intellectual potential. Stimulation needs to be given when the child is ready to learn something, so that children's intelligence develops well, since the age of a toddler, a child needs to be given a variety of directed stimuli.

The success of a student in education is not only determined by the level of intelligence but also influenced by other factors, such as environmental factors, personality, motivation, interests. In general, it can be said that the possibility of succeeding in education for someone who has a high level of intelligence is greater than the possibility of success for someone who has a lower level of intelligence. But, not always the level of intelligence is in line with the success of achievement. Therefore, a high level of intelligence does not necessarily guarantee a person's success, if not supported by other non-intelligent factors [6].

The factors that determine the success of a student in his education are determined by internal and external factors of these students. Internal factors include namely, intelligence, talent, motivation, and personality. These factors are interrelated and affect each other. Intelligence will optimally function when supported by talent factors, strong and appropriate motivation and personality traits. Motivational factors are not something static but can be changed and intensified with the help of the surrounding environment, namely by parents, teachers, peers, psychologists, doctors or social workers, and so on. To increase the achievement of desires in education, one way is to increase the knowledge, skills, and attitudes of parents and teachers to create a conducive environment in improving children's performance at home and at school.
Ref [13] also explained that intelligence tests could be used to help smooth education. General intelligence tests can be used for selection and diagnostic purposes. Certain circumstances personality tests are very necessary to determine the right steps in an effort to overcome learning obstacles that are not solely caused by intelligence.

This condition can also be explained by the opinion of Sandoval in [14], that the use of WISC as a single measure to measure attention and concentration is inappropriate and not justified, it is necessary to consider various other measuring instruments available. Millich \& Loney in [14] also suggests not using WISC to measure the attention of hyperactive children.

The level of intelligence of children with ADHD generally varies from below average to above average or higher. Not true the opinion of parents and teachers that children with ADHD must have a low level of intelligence. The results of this study have shown various limitations experienced by children with ADHD. Therefore it is necessary to consider further how efforts can be made to help children with ADHD adjust to the demands of studying at school.

\section{CONCLUSION AND RECOMMENDATION}

It can be concluded that the intelligence of students with ADHD barriers lies in the category above the average, average, below average, border and mental retardation.

Future researchers are expected to conduct research by looking at the characteristics of students who have ADHD barriers. The WISC test can contribute meaningfully in revealing the developmental characteristics of the intelligence aspects of children with ADHD that support their cognitive, academic, social, and emotional problems.

Teachers and the school should be willing to cooperate with parents to help children with ADHD adjust to the demands of studying at school and improve their social skills.

\section{REFERENCES}

[1] F. Mangunsong, Psikologi dan pendidikan anak berkebutuhan khusus, Depok: LPSP3 UI, 2014.

[2] D.P. Hallahan, J.M. Kauffman and P. G. Pullen. Exceptional children: an introduction to special education (11th Ed). Boston: Allyn \& Bacon, 2009.

[3] H. C. Parker, The ADD hyperactivity handbook for schools: Effective strategies for identifying and teaching students with attention deficit disorders in elementary and secondary schools, Florida: Impact Publications, 1992.

[4] S. Reif, The ADHD book of lists, San Fransisco: Jossey Bass, 2003.

[5] J. M. Sattler, Assessment of children's intelligence, USA: W.B. Saunders Company. 1974.

[6] A. P. Dayu, Mendidik Anak ADHD (Attention Deficit and Hyperactivity Disorder), Yogyakarta: Javalitera, 2013.

[7] M. Ulfah. Pedologi attention deficit and hyperactivity disorder (ADHD), Program Studi Psikologi. Unpublished, 2015.

[8] B. Baihaqi and Sugiamin, Memahami dan membantu anak ADHD, Bandung: PT. Refika Aditama, 2006.

[9] R. A. Barkle, Attention deficit hyperactivity disorder, Retrieved September 1998, from http://www.chadd.org., 1998.

[10] B. Delphie, Pembelajaran anak berkebutuhan khusus (Dalam Setting Pendidikan Inklusi), Bandung: PT. Refika Aditama, 2006. 
[11] A. Arikunto, Prosedur Penelitian: Suatu Pendekatan Praktek, Edisi Revisi VI, Jakarta : PT Rineka Cipta, 2005.

[12] S. Sugiyono. 2010. Metode Penelitian Kuantitatif Kualitatif, Bandung: Alfabeta, 2010.

[13] S. Sadli, et al., Inteligensi Bakat dan Test IQ, Jakarta : PT. Gaya Favorit Press, 1986.

[14] D. M. Ross, and S. A Ross. Hyperactivity: Current issues, research and theory, New York: John Wiley and Sons, 1982. 